\title{
The influence of Service Quality, Promotion, and Brand Image on Decision Making of Gojek Service Users to Students in Tembalang
}

\author{
Dandi David Nababan, Makmun Riyanto, Paniya* \\ Applied Business Administration, State Politechnic of Semarang, Indonesia
}

\begin{abstract}
This study aims to determine the effect of Service Quality, Promotion, and Brand Image on Decision Making of Gojek Service Users (A Case Study of Students Using Gojek Services in Tembalang Semarang). The data collection method is done by literature review and using a questionnaire. The questionnaire used is the Agree-Disagree Scale with a scale of 10. The sampling method using a purposive sampling method of 150 samples. Data processing is conducted using SPSS 24. Based on the calculations that have been done, the results of the t test show that each variable accepts Hal, Ha2, dan Ha3, so that the variables of Service Quality (X1), Promotion (X2), and Brand Image (X3) have a significant effect on the use decision variable $(Y)$. The F test shows that Ho4 is rejected and Ha4 is accepted, which means that the variables of Service Quality (X1), Promotion (X2), and Brand Image (X3) simultaneously influence the Use Decision variable $(Y)$. Then the results of the determination coefficient test show a value of 0.605, which means that $60.5 \%$ of the Use Decision variable $(Y)$ can be explained by the variables of Service Quality (X1), Promotion (X2), and Brand Image (X3) and the remaining $39.5 \%$ is influenced by factors others who were not included in this study.
\end{abstract}

Keywords: Service Quality, Promotion, Brand Image, Use Decision. 


\title{
Pengaruh Kualitas Layanan, Promosi, dan Citra Merek terhadap Pengambilan Keputusan Pengguna Jasa Gojek pada Mahasiswa di Tembalang
}

\begin{abstract}
Abstrak
Penelitian ini bertujuan untuk mengetahui pengaruh Kualitas Layanan, Promosi, dan Citra Merek terhadap Pengambilan Keputusan Pengguna Layanan Jasa Gojek (Studi Kasus Pada Mahasiswa Pengguna Jasa Gojek di Tembalang Semarang). Metode pengumpulan data dilakukan dengan menggunakan studi pustaka kuesioner. Kuesioner yang digunakan adalah Agree-Disagree Scale dengan skala 10. Pengumpulan sampel menggunakan metode purposive sampling yaitu sebanyak 150 sampel. Pengolahan data dilakukan menggunakan SPSS 24. Berdasarkan perhitungan yang telah dilakukan, hasil uji t menunjukkan bahwa setiap variabel menerima Ha1, Ha2, dan Ha3, sehingga variabel Kualitas Layanan (X1), Promosi (X2), dan Citra Merek (X3) berpengaruh signifikan terhadap variabel keputusan penggunaan (Y). Uji F menunjukkan bahwa Ho4 ditolak dan Ha4 diterima, yang berarti bahwa variabel Kualitas Layanan (X1), Promosi (X2), dan Citra Merek (X3) berpengaruh secara simultan terhadap variabel Keputusan Penggunaan (Y). Kemudian hasil uji koefisien determinasi menunjukkan nilai sebesar 0.605 , yang artinya $60.5 \%$ variabel Keputusan Penggunaan (Y) dapat dijelaskan oleh variabel Kualitas Layanan (X1), Promosi (X2), dan Citra Merek (X3) dan sisanya sebesar $39.5 \%$ dipengaruhi oleh faktor lain yang tidak termasuk dalam penelitian ini.
\end{abstract}

Kata Kunci: Kualitas Layanan, Promosi, Citra Merek, Keputusan Penggunaan. 


\section{PENDAHULUAN}

Pada tanggal 1 Mei 2019 Menteri Perhubungan menetapakan tarif ojek online naik. Tarif baru ini tertuang dalam keputusan Menteri Perhubungan nomor 384 tahun 2019. Dalam keputusan ini, ada dua komponen penyusun tarif ojek online. Pertama, biaya langsung yang ditetapkan oleh Kementerian Perhubungan dan biaya tidak langsung yang ditetapkan aplikator dengan besaran maksimal $20 \%$ dari total biaya langsung. (CNBC Indonesia, 2019)

Kemenhub menyusun tarif langsung berdasarkan zonasi:

- Zona I (Sumatra, Jawa, Bali kecuali Jabodetabek): $\mathrm{Rp}$ 1.850-2.300 per $\mathrm{km}$ dengan biaya minimal Rp 7.000-10.000

- Zona II (Jabodetabek): Rp 2.000-2.500 per $\mathrm{km}$ dengan biaya minimal $\mathrm{Rp}$ 8.00010.000

- Zona III (Kalimantan, Sulawesi, NTT, Maluku, dan lainnya): Rp 2.100-2.600 dengan biaya minimal Rp 7.000-10.000.

Penetapan tarif baru ini membawa dampak yang cukup besar terutama bagi masyarakat atau konsumen ojek online. Survei Research Institute of Socio-Economic Development (RISED) terhadap 2.001 pengguna ojek online di 10 provinsi menunjukkan, 45,83\% responden menyatakan tarif saat ini sudah sesuai. 28\% responden lainnya mengaku bahwa tarif ojek online saat ini sudah mahal, bahkan sangat mahal. Pada survei, $48,13 \%$ responden hanya mau mengeluarkan biaya tambahan kurang dari $\mathrm{Rp}$ 5 ribu per hari. Sebanyak 23\% responden lainnya tidak ingin mengeluarkan biaya tambahan sama sekali. Dari hasil survei yang dilakukan RISED diketahui bahwa jarak tempuh rata-rata konsumen adalah $8,8 \mathrm{~km}$ per hari. Dengan jarak tempuh sejauh itu, apabila terjadi kenaikan tarif dari $\mathrm{Rp} 2.200$ per kilometer menjadi Rp 3.100 per kilometer, maka pengeluaran konsumen akan bertambah sebesar Rp 7.920 per hari (Katadata.co.id, 2019)

Namun Gojek bukanlah satu-satunya transportasi online yang ada di Indonesia.
Saat ini ada beberapa perusahaan transportasi online yang menjadi kompetitor Gojek yang menuntut Gojek meningkatkan kualitasnya agar tidak mudah tersalip oleh kompetitornya, salah satunya adalah Grab.

Salah satu perbedaan antara Gojek dan Grab dapat dilihat dari tarif yang dikenakan pada pengguna jasa. Berdasarkan informasi bahwa Gojek memiliki tarif sebesar 12.000 rupiah untuk perjalanan $1-10 \mathrm{~km}$. Saat melakukan perjalanan 11-15 km maka Gojek akan mematok tarif sebesar 15.000 rupiah dan jika melakukan perjalanan lebih dari $15 \mathrm{~km}$ maka Gojek akan menambah biaya tambahan sebesar 2.000 rupiah per satu kilometernya. Tarif tersebut berlaku pada jam-jam biasa, jika pada saat jam sibuk maka akan ada biaya yang berbeda. Untuk jam sibuk akan dikenakan biaya tambahan 5.000 rupiah yang artinya tarif lebih mahal dibandingkan pada saat jam biasa. Jam sibuk yakni pada pagi hari dari jam 06.00-09.00 dan sore 16.00-19.00.

Sedangkan untuk Grab, tarif yang diberikan 1.750 rupiah per kilometer untuk 12 $\mathrm{km}$ pertama, diatas $12 \mathrm{~km}$ ada penambahan 3.000 rupiah per kilometer dan biaya tambahan pada jam sibuk sebesar 2.500 rupiah (ojekonline.co.id, 2020)

Dari penjelasan di atas dapat dilihat bahwa harga Grab lebih murah dari Gojek, akan tetapi pada hasil survei "Consumer's Awareness" yang dilakukan oleh Spire Research and Consulting Gojek masih menjadi pilihan utama pengguna transportasi online pada kategori roda dua. Dari total responden yang memilih Go-Ride, sebanyak 64\% menggunakannya hingga 1-2 kali sehari, sedangkan pemilih GrabBike yang menggunakan 1-2 kali sehari ada sebanyak 58\% (Gadgetsquad.id, 2019)

Uraian diatas merupakan alasan penulis dalam menjadikan Gojek sebagai objek penelitian. Responden pada penelitian ini adalah mahasiswa yang ada di Tembalang. Pada kecamatan Tembalang terdapat tujuh perguruan tinggi, yang mana lokasi kampus sangat strategis, sangat mudah dijangkau baik Gojek maupun Grab. Tidak hanya transportasi 
online, ketujuh kampus ini juga dapat dijangkau oleh angkutan umum lainnya seperti BRT dan Taxi.

\section{Perumusan Masalah}

Berdasarkan uraian diatas, perumusan masalah dalam penelitian ini adalah sebagai berikut:

a. Bagaimana pengaruh kualitas layanan terhadap pengambilan keputusan pengguna Gojek pada mahasiswa di Tembalang?

b. Bagaimana pengaruh promosi terhadap pengambilan keputusan pengguna Gojek pada mahasiswa di Tembalang?

c. Bagaimana pengaruh citra merek terhadap pengambilan keputusan pengguna Gojek pada mahasiswa di Tembalang?

d. Bagaimana pengaruh kualitas layanan, promosi, dan citra merek secara simultan terhadap keputusan pengguna Gojek pada mahasiswa di Tembalang?

\section{Tujuan Penelitian}

Adapun tujuan penelitian yang ingin dicapai dalam penelitian ini adalah sebagai berikut:

a. Untuk mengetahui bagaimana pengaruh kualitas layanan terhadap pengambilan keputusan pengguna Gojek pada mahasiswa di Tembalang.

b. Untuk mengetahui bagaimana pengaruh promosi terhadap pengambilan keputusan pengguna Gojek pada mahasiswa di Tembalang.

c. Untuk mengetahui bagaimana pengaruh citra merek terhadap pengambilan keputusan pengguna Gojek pada mahasiswa di Tembalang.

d. Untuk mengetahui bagaimana pengaruh kualitas layanan, promosi, dan citra merek secara simultan terhadap keputusan pengguna Gojek pada mahasiswa di Tembalang.

\section{Tinjauan Pustaka}

Pengambilan Keputusan Penggunaan
Menurut Schiffman \& Kanuk dalam Wahyuni dan Waloejo (2020) secara umum, keputusan adalah pemilihan dari dua atau lebih alternatif pilihan. Dengan kata lain untuk membuat keputusan harus terdapat alternatif pilihan. Sebaliknya jika konsumen tidak memiliki alternatif untuk memilih maka tidak dapat dikategorikan sebagai pengambilan keputusan.

\section{Indikator Pengambilan Penggunaan}

Menurut Kotler dan Keller dalam Yunanto (2016) proses pengambilan keputusan terdiri dari 5 tahapan, yaitu:

a. Problem Recognition (pengenalan masalah)

b. Information search (pencarian informasi)

c. Evaluation of alternative (evaluasi alternatif)

d. Purchase decision (keputusan pembelian)

e. Postpurchase behavior (perilaku pasca pembelian)

\section{Kualitas Layanan}

Menurut Kotler dalam Marlius dan Putriani (2020), merumuskan bahwa kualitas merupakan suatu kondisi dinamis yang berhubungan dengan produk, jasa, manusia, proses, dan lingkungan yang memenuhi atau melebihi harapan.

\section{Indikator Kualitas Layanan}

Menurut Parasuraman et al. dalam Wahyuni dan Waloejo (2020) merangkum menjadi 5 demensi pokok kualitas layanan, yaitu:

a. Bukti langsung (tangibles)

b. Keandalan (reliability)

c. Daya tanggap (Responsiveness)

d. Jaminan (assurance)

e. Empati (emphaty)

\section{Promosi}

Menurut A. Hamdani dalam Fajarini dan Harjawati (2018) Promosi adalah salah satu variabel dalam bauran pemasaran yang sangat 
penting dilaksanakan oleh perusahaan dalam memasarakan produk. Kegiatan promosi bukan saja berfungsi sebagai alat komunikasi antara perusahaan dengan konsumen, melainkan juga sebagai alat untuk mempengaruhi konsumen dalam kegiatan pembelian atau penggunaan produk sesuai dengan kebutuhan dan keinginannya.

\section{Indikator Promosi}

Menurut Kotler dalam Prawira dan Pangestuti (2019) bauran promosi adalah esensi promosi dari promosi dan bagaimana promosi dilakukan secara efektif. Alat bauran promosi terdiri dari:

a. Periklanan (advertising)

b. Promosi penjualan (sales promotion)

c. Hubungan masyarakat (public relations)

d. Pemasaran langsung (direct marketing)

\section{Citra Merek}

Citra merek menurut Kotler dan Keller dalam Yunanto (2016) adalah presepsi dan keyakinan yang dipegang oleh konsumen, seperti yang dicerminkan asosiasi yang tertanam dalam ingatan konsumen. Kotler juga mengungkapkan bahwa sikap dan Tindakan seseorang terhadap suatu objek sangat dikondisikan oleh citra objek tersebut.

\section{Indikator Citra Merek}

Menurut Kotler dan Keller dalam Yunanto (2016) bahwa pengukuran citra merek dapat dilakukan berdasarkan pada aspek sebuah merek yaitu:
a. Kekuatan (strength)
b. Keunikan (uniqueness)
c. Kesukaan (favorabel)

\section{METODE PENELITIAN \\ Populasi dan Sampel}

Di dalam penelitian ini, yang menjadi populasi yaitu mahasiswa yang ada di Tembalang, Semarang yang menggunakan jasa Gojek. Teknik sampel yang digunakan yaitu purposive sampling, dan jumlah sampel yang digunakan berjumlah 150 responden.

\section{Teknik Pengumpulan Data}

Teknik pengumpulan data yang digunakan dalam penelitian ini yaitu kuesioner dan studi pustaka. Kuesioner yang digunakan dalam penelitian ini adalah skala pengukuran agree disagree scale dengan rentang 1-10.

\section{Teknik Pengumpulan Data}

Teknik analisis yang digunakan dalam penelitian ini yaitu analisis regresi linear berganda dengan menggunakan SPSS 24. Hasil analisis data terdiri dari uji validitas dan uji reliabilitas, uji asumsi klasikm, dan uji signifikansi. 


\section{HASIL DAN PEMBAHASAN}

Tabel 1. Hasil Uji Validitas

\begin{tabular}{|c|c|c|c|c|}
\hline Variabel & Indikator & r hitung & $r$ tabel & Keterangan \\
\hline \multirow{10}{*}{$\begin{array}{l}\text { Kualitas } \\
\text { Layanan }\end{array}$} & \multirow{2}{*}{ Reliability } & 0.718 & 0.1603 & Valid \\
\hline & & 0.800 & 0.1603 & Valid \\
\hline & \multirow{2}{*}{ Responsivenes } & 0.673 & 0.1603 & Valid \\
\hline & & 0.832 & 0.1603 & Valid \\
\hline & \multirow{2}{*}{ Assurance } & 0.799 & 0.1603 & Valid \\
\hline & & 0.847 & 0.1603 & Valid \\
\hline & \multirow{2}{*}{ Empathy } & 0.751 & 0.1603 & Valid \\
\hline & & 0.821 & 0.1603 & Valid \\
\hline & \multirow{2}{*}{ Tangible } & 0.797 & 0.1603 & Valid \\
\hline & & 0.752 & 0.1603 & Valid \\
\hline \multirow{9}{*}{ Promosi } & \multirow{2}{*}{ Advertising } & 0.680 & 0.1603 & Valid \\
\hline & & 0.741 & 0.1603 & Valid \\
\hline & \multirow{3}{*}{ Sales Promotion } & 0.758 & 0.1603 & Valid \\
\hline & & 0.755 & 0.1603 & Valid \\
\hline & & 0.821 & 0.1603 & Valid \\
\hline & \multirow{2}{*}{ Hubungan Masyarakat } & 0.810 & 0.1603 & Valid \\
\hline & & 0.792 & 0.1603 & Valid \\
\hline & \multirow{2}{*}{ Pemasaran Langsung } & 0.727 & 0.1603 & Valid \\
\hline & & 0.688 & 0.1603 & Valid \\
\hline \multirow{6}{*}{ Citra Merek } & \multirow{3}{*}{ Strength } & 0.763 & 0.1603 & Valid \\
\hline & & 0.849 & 0.1603 & Valid \\
\hline & & 0.685 & 0.1603 & Valid \\
\hline & Uniquess & 0.763 & 0.1603 & Valid \\
\hline & \multirow[t]{2}{*}{ Favourable } & 0.770 & 0.1603 & Valid \\
\hline & & 0.776 & 0.1603 & Valid \\
\hline \multirow{11}{*}{$\begin{array}{l}\text { Keputusan } \\
\text { Penggunaan }\end{array}$} & Pengenalan Masalah & 0.747 & 0.1603 & Valid \\
\hline & \multirow{4}{*}{ Pencarian Informasi } & 0.670 & 0.1603 & Valid \\
\hline & & 0.676 & 0.1603 & Valid \\
\hline & & 0.659 & 0.1603 & Valid \\
\hline & & 0.701 & 0.1603 & Valid \\
\hline & Evaluasi Alternatif & 0.792 & 0.1603 & Valid \\
\hline & \multirow{2}{*}{ Keputusan Pembelian } & 0.817 & 0.1603 & Valid \\
\hline & & 0.827 & 0.1603 & Valid \\
\hline & \multirow{3}{*}{$\begin{array}{l}\text { Perilaku Pasca } \\
\text { Pembelian }\end{array}$} & 0.817 & 0.1603 & Valid \\
\hline & & 0.812 & 0.1603 & Valid \\
\hline & & 0.841 & 0.1603 & Valid \\
\hline
\end{tabular}

Sumber: Data primer yang diolah, 2020

\section{Uji Validitas}

Uji validitas menurut Ghozali (2016) digunakan untuk mengetahui kelayakan butirbutir dalam suatu daftar pertanyaan dalam mendefinisikan suatu variabel.
Berdasarkan Tabel 1 dapat disimpulkan bahwa semua indikator variabel Kualitas Layanan, Promosi, Citra Merek, dan Keputusan Penggunaan adalah valid. 


\section{Uji Reliabilitas}

Uji reliabilitas menurut Ghozali (2016) bertujuan untuk mengetahui sejauh mana suatu hasil pengukuran relative konsisten bila pengukuran diulang dua kali atau lebih.

Tabel 2. Hasil Uji Reliabilitas

\begin{tabular}{|l|c|c|c|}
\hline \multicolumn{1}{|c|}{ Variabel } & $\begin{array}{c}\text { Cronbach } \\
\text { Alpha }\end{array}$ & $\begin{array}{c}\text { Standart } \\
\text { Alpha }\end{array}$ & Keterangan \\
\hline Kualitas Layanan (X1) & 0.927 & 0.7 & Reliabel \\
\hline Promosi (X2) & 0.904 & 0.7 & Reliabel \\
\hline Citra Merek (X3) & 0.860 & 0.7 & Reliabel \\
\hline Keputusan Penggunaan (Y) & 0.927 & 0.7 & Reliabel \\
\hline
\end{tabular}

Sumber: Data primer yang diolah, 2020

Dari Tabel 2 dapat dilihat bahwa keempat variabel yang digunakan dalam penelitian ini dinyatakan reliabel karena nilai Cronbach Alpha masing-masing variabel tersebut lebih dari 0.7.

\section{Uji Asumsi Klasik}

\section{Uji Normalitas}

Uji normalitas menurut Ghozali (2016) berguna untuk mengetahui apakah populasi data berdistribusi normal atau tidak.

Berdasarkan hasil uji normalitas menggunakan Monte Carlo, didapatkan nilai signifikan sebesar 0.126 lebih besar dari 0.05, maka data dinyatakan berdistribusi normal.

\section{Uji Multikolonieritas}

Berdasarkan hasil uji multikolinearitas menunjukan bahwa nilai nilai VIF Kualitas Layanan (X1) sebesar 1.658, Promosi (X2) sebesar 2.215, Citra Merek (X3) sebesar 1.748 yang artinya nilai VIF dari hasil uji tersebut lebih kecil dari pada 10 dan nilai Tolerance $>0.10$ yaitu Kualitas Layanan (X1) sebesar 0.603, Promosi (X2) sebesar 0.0451, dan Citra Merek (X3) sebesar 0.572 sehingga dapat disimpulkan bahwa tidak terjadi gerjala multikolinieritas diantara variabel.

\section{Uji Heteroskedastisitas}

Uji Heteroskedastisitas menurut Ghozali (2016) bertujuan untuk menguji apakah dalam model regresi terjadi ketidaksamaan varian dari residual satu pengamatan ke pengamatan lain.

Berdasarkan hasil uji heteroskedastisitas diketahui nilai Sig Kualitas Layanan (X1) sebesar 0.389, Promosi (X2) sebesar 0.389, dan Citra Merek (X3) sebesar 0.794 yang artinya nilai Sig $\geq 0,05$ sehingga dapat disimpulkan bahwa tidak terjadi gerjala heterokedastisitas pada model regresi.

\section{Analisis Regresi Linear Berganda}

Menurut Sugiyono dalam Pusparani dan Krisnawati (2019) analisis regresi linear berganda digunakan untuk meramalkan bagaimana keadaan (naik turunnya) variabel terikat, bila dua atau lebih variabel bebas, sebagai faktor prediator, dimanipulasi (dinaikturunkan nilainya). Maka analisis ini akan digunakan apabila terdapat 2 variabel bebas. 
Tabel 3. Hasil Analisis Regresi

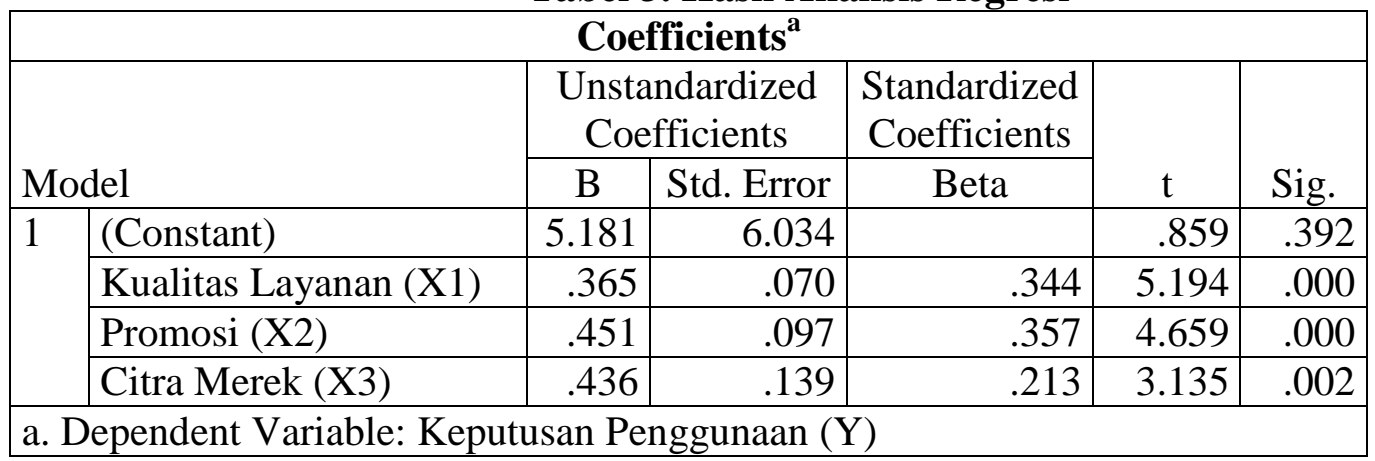

Sumber: Data primer yang diolah, 2020

Berdasarkan Tabel 3 dapat dibuat persamaan regresi sebagai berikut:

\section{$Y=5.181+0.365 X 1+0.451 X 2+$ $0.436 \times 3$}

Dari persamaan diatas diketahui konstanta sebesar 5.181, menyatakan bahwa jika Kualitas Layanan (X1), Promosi (X2), dan Citra Merek (X3) bernilai 0 (nol), maka variabel Keputusan Penggunaan (Y) sebesar 5.181.

a. Variabel Kualitas Layanan (X1)

Variabel Kualitas Layanan (X1) berpengaruh positif terhadap variabel Keputusan Penggunaan (Y) dengan nilai koefisien sebesar 0.365, yang berarti bahwa setiap kenaikan variabel Kualitas Pelayanan (X1) akan menaikan variabel Keputusan Penggunaan (Y) sebesar 0.365 .

b. Variabel Promosi (X2)

Variabel Promosi (X2) berpengaruh positif terhadap variabel Keputusan Penggunaan (Y) dengan nilai koefisien sebesar 0.451, yang berarti bahwa setiap kenaikan variabel Promosi (X2) akan menaikan variabel Keputusan Penggunaan (Y) sebesar 0.451.

c. Variabel Citra Merek (X3)

Variabel Citra Merek (X3) berpengaruh positif terhadap variabel Keputusan Penggunaan ( $Y$ ) dengan nilai koefisien sebesar 0.436, yang berarti bahwa setiap kenaikan variabel Citra Merek (X3) akan menaikan variabel Keputusan Penggunaan (Y) sebesar 0.436 .

\section{Uji Signifikan}

\section{Uji t (Uji Parsial)}

a. Pengujian Hipotesis Kualitas Layanan (X1) terhadap Keputusan Penggunaan (Y)

Ho1 = Variabel Kualitas Layanan (X1) tidak berpengaruh secara signifikan terhadap variabel Keputusan Penggunaan (Y).

Ha1 $=$ Variabel Kualitas Layanan (X1) berpengaruh secara signifikan terhadap variabel Keputusan Penggunaan (Y).

Pada hasil pengujian yang dilakukan $\mathrm{t}$ hitung Kualitas Layanan sebesar 5.194 lebih besar dari t tabel sebesar 1.97623 serta nilai signifikansi 0.000 lebih kecil dari 0.05, maka Hol ditolak dan Hal diterima. Dengan demikian dapat disimpulkan bahwa terdapat pengaruh yang signifikan Kualitas Layanan (X1) terhadap Keputusan Penggunaan (Y).

b. Pengujian Hipotesis Promosi (X2) terhadap Keputusan Penggunaan (Y)

Ho2 = Variabel Promosi (X2) tidak berpengaruh secara signifikan terhadap variabel Keputusan Penggunaan (Y).

$\mathrm{Ha} 2=$ Variabel Promosi (X2) berpengaruh secara signifikan terhadap variabel Keputusan Penggunaan (Y).

Pada hasil pengujian yang dilakukan $\mathrm{t}$ hitung Kualitas Layanan sebesar 4.659 
lebih besar dari t tabel sebesar 1.97623 serta nilai signifikansi 0.000 lebih kecil dari 0.05 , maka $\mathrm{Ho} 2$ ditolak dan $\mathrm{Ha} 2$ diterima. Dengan demikian dapat disimpulkan bahwa terdapat pengaruh yang signifikan Promosi Penjualan (X2) terhadap Keputusan Penggunaan (Y).

c. Pengujian Hipotesis Citra Merek (X3) terhadap Keputusan Penggunaan (Y)

Ho3 = Variabel Promosi Penjualan (X2) tidak berpengaruh secara signifikan terhadap variabel Keputusan Penggunaan (Y).

$\mathrm{Ha} 3=$ Variabel Promosi Penjualan (X2) berpengaruh secara signifikan terhadap variabel Keputusan Penggunaan ( $\mathrm{Y}$ ).

Pada hasil pengujian yang dilakukan $\mathrm{t}$ hitung Kualitas Layanan sebesar 3.135 lebih besar dari t tabel sebesar 1.97623 serta nilai signifikansi 0.000 lebih kecil dari 0.05 , maka $\mathrm{Ho} 3$ ditolak dan $\mathrm{Ha} 3$ diterima. Dengan demikian dapat disimpulkan bahwa terdapat pengaruh yang signifikan Citra Merek (X3) terhadap Keputusan Penggunaan (Y).

\section{Uji F (Uji Simultan)}

Uji F menurut Ghozali (2016) semua variabel independen yang dimasukan dalam model mempunyai pengaruh secara bersamasama terhadap variabel dependen.

Ho4 = Variabel Kualitas Layanan (X1), Promosi (X2), Citra Merek (X3) tidak berpengaruh secara signifikan terhadap variabel Keputusan Penggunaan (Y).

Ha4 $=$ Variabel Kualitas Layanan (X1), Promosi (X2), Citra Merek (X3) berpengaruh secara signifikan terhadap variabel Keputusan Penggunaan (Y).

Pada hasil pengujian yang dilakukan $\mathrm{F}$ hitung sebesar 77.118 sedangkan $\mathrm{F}$ tabel sebesar 2.67. ( $\mathrm{F}$ hitung (77.118) $>\mathrm{F}$ tabel (2.67)), serta nilai signifikansi sebesar 0.000 . Maka dengan ini dapat disimpulkan bahwa Ho4 ditolak dan Ha4 diterima yang berarti variabel Kualitas Layanan (X1), Promosi (X2), dan Citra Merek (X3) berpengaruh signifikan terhadap variabel Keputusan Penggunaan (Y).

\section{Koesfisien Determinasi}

Menurut Ghozali (2016) koefisien determinasi $\left(\mathrm{R}^{2}\right)$ pada dasarnya mengukut seberapa jauh kemampuan model dalam menerangkan variabel dependen.

Berdasarkan hasil uji koefisien determinasi diketahui nilai Adjusted R Square adalah 0.605 atau $60.5 \%$. Artinya besarnya pengaruh Kualitas Layanan (X1), Promosi (X2), dan Citra Merek (X3) terhadap Pengambilan Keputusan Pengguna Jasa Gojek (Y) adalah sebesar $60.5 \%$ dan sisanya dipengaruhi oleh variabel lain yang tidak diteliti dalam penelitian ini.

\section{KESIMPULAN}

Berdasarkan hasil penelitian dan analisis data mengenai pengaruh Kualitas Layanan, Promosi, dan Citra Merek terhadap Keputusan Pengguna Jasa pada mahasiswa di Tembalang seperti yang telah dijelaskan pada bab-bab sebelumnya, maka kesimpulan yang dapat diambil adalah sebagai berikut:

a. Berdasarkan hasil uji $\mathrm{t}$ variabel Kualitas Layanan, Promosi, dan Citra Merek secara parsial berpengaruh positif terhadap Pengambilan Keputusan Pengguna Jasa Gojek pada Mahasiswa di Tembalang. Variabel Kualitas Layanan, Promosi Penjualan, dan Citra Merek menerima Ha dan menolak Ho.

b. Berdasarkan hasil uji F variabel Kualitas Layanan, Promosi, dan Citra Merek secara simulatan berpengaruh terhadap Pengambilan Keputusan Pengguna Jasa Gojek pada Mahasiswa di Tembalang.

c. Terdapat pengaruh signifikan antara Kualitas Layanan (X1), Promosi (X2), dan Citra Merek (X3) terhadap Pengambilan Keputusan Penggunaan (Y). Perhitungan analisi regresi linear 
berganda menggunakan SPSS 24 didapatkan persamaan sebagai berikut:

$$
\begin{gathered}
Y=5.181+0.365 \mathrm{X} 1+0.451 \mathrm{X} 2+ \\
0.436 \mathrm{X} 3
\end{gathered}
$$

Dilihat dari persamaan tersebut dapat diketahui bahwa nilai koefisien regresi variabel Kualitas Layanan (X1) sebesar 0.365 , variabel Promosi (X2) sebesar 0.451, dan variabel Citra Merek (X3) sebesar 0.436. Hal ini menunjukkan bahwa variabel Promosi (X2) memiliki pengaruh paling besar terhadap Pengambilan Keputusan Pengguanan (Y) dalam menggunakan jasa Gojek.

d. Hasil koefisien (Adjusted $R$ Square) sebesar 0.605. Sehingga dapat disimpulkan bahwa variabel independen yaitu Kualitas Layanan (X1), Promosi (X2), dan Citra Merek (X3) mempengaruhi variabel dependen yaitu Pengambilan Keputusan Penggunaan (Y) sebesar $60.5 \%$, sedangkan sisanya $100 \%$ $-60.5 \%=39.5 \%$ dipengaruhi oleh faktor lain yang tidak termasuk dalam penelitian ini.

\section{Saran}

Berdasarakan hasil penelitian mengenai pengaruh Kualitas Layanan, Promosi Penjualan, dan Citra Merek terhadap Pengambilan Keputusan Pengguna Jasa Gojek pada Mahasiswa Tembalang, maka saran yang dapat diberikan adalah sebagai berikut:

a. Hasil analisis regresi linear berganda pada penelitian ini menunjukkan bahwa variabel Kualitas Layanan memiliki pengaruh yang positif dan signifikan terhadap keputusan menggunakan Gojek, meskipun di banding variabel yang lain pengaruhnya yang paling rendah. Karena itu Kualitas Layanan juga harus ditingkatkan.

Pada indikator variabel Kualitas Layanan, yaitu indikator responsiveness merupakan indikator yang memiliki nilai indeks paling rendah dibandingkan dengan indikator lainnya, hal ini berarti respon yang diberikan belum maksimal, karena itu unsur indikator responsiveness hendak ditingkatkan dengan cara memperhatikan ketepatan waktu dalam menjemput dan mengantar pelanggan, sehingga pelanggan akan merasa nyaman ketika menggunakan Gojek.

Selain itu Kualitas Layanan dapat ditingkatkan dengan memperhatikan keadaan kendaraan tetap baik, atribut berkendara lengkap, driver berkomunikasi dengan baik dan sopan kepada pelanggan.

b. Pada penelitian ini, berdasarkan hasil analisis regresi linear berganda variabel Promosi Penjualan memiliki pengaruh yang paling besar terhadap Pengambilan Keputusan Pengguna Jasa Gojek pada Mahasiswa Tembalang.

c. Promosi Penjualan juga merupakan variabel dengan nilai indeks paling besar, hal ini menandakan promosi yang dilakukan perusahaan telah baik. Namun pada analisis deskripsi variabel Promosi Penjualan, "memberi informasi" merupakan indikator dengan nilai indeks paling rendah, ini bisa berarti pemeberian informasi belum maksimal. Untuk itu perusahaan perlu membuat iklan yang dapat menyampaikan informasi mengenai fitur-fitur atau layanan yang tersedia di Gojek. Selain itu perusahaan dapat melakukan promosi penjualan dengan cara memberikan diskon baik kepada pengguna baru atau pengguna lama, memberikan harga khusus ketika pelanggan melakukan pembayaran menggunakan Go-Pay, Gojek selalu menjalin hubungan baik dengan pelanggannya, dan juga memberi kemudahan kepada pelanggan ketika menggunakan fitur-fitur yang ada pada aplikasi mobile Gojek.

d. Berdasarkan hasil analisis regresi linear berganda pada penelitian ini variabel Citra Merek memiliki pengaruh positif terhadap Pengambilan Keputusan Pengguna Jasa Gojek pada Mahasiswa Tembalang. 
Citra Merek juga memiliki nilai indeks yang tinggi. Hal ini bisa berarti perusahaan memiliki citra merek yang baik.

Pada analisis deskripsi salah satu indikator variabel Citra Merek, "berbeda dengan produk lain" merupakan indikator dengan nilai indeks paling kecil, hal ini bisa berarti produk Gojek tidak berbeda dengan yang lain. Untuk itu perusahaan perlu melakukan inovasi agar fitur dan layanan yang ditawarkan memiliki keunikan sehingga dapat dikenali pelanggan dengan mudah. Disamping itu untuk meningkatkan Citra Merek perusahaan juga dapat melakukannya dengan cara memperhatikan selera pelanggan sehingga perusahaan dapat menawarkan layanan sesuai dengan kebutuhan pelanggan.

\section{DAFTAR PUSTAKA}

Fajarini, U., \& Harjawati, T. (2018). Pengaruh harga pelayanan dan promosi terhadap keputusan penggunaan jasa angkutan gojek pada mahasiswa jurusan pendidikan IPS UIN Syarif Hidayatullah Jakarta (Bachelor's thesis, UIN Syarif Hidayatullah Jakarta: Fakultas Ilmu Tarbiyah dan Keguruan, 2018).

Gadgetsquad.id, "Gojek vs Grab ,mana yang paling banyak dipakai pengguna?" 31 Januari 2019. https://gadgetsquad.id/versus/gojek-vsgrab/ (Diakses pada 20 Juni 2020)

Ghozali. 2016. Aplikasi Analisis Multivariete Dengan Program IBM SPSS 23. Semarang: Badan Penerbit Universitas Diponegoro

Kumparan.com, "RIset:64\% penduduk Indonesia sudah pakai internet”, 21 Februari 2020. https://kumparan.com/kumparantech/ris et-64-penduduk-indonesia-sudah-pakai-
internet-1ssUCDbKILp/full (Diakses pada 18 Juni 2020)

Marlius, D., \& Putriani, I. (2020). Kepuasan Nasabah PT. Bank Rakyat Indonesia Unit Tapan Cabang Painan Dilihat dari Kualitas Layanan Customer Service. Jurnal Pundi, 3(2), 111-122.

Prawira, S. H., \& Pangestuti, E. (2019). Pengaruh Bauran Promosi Terhadap Keputusan Menginap (Survei Pada Wisatawan Yang Menginap Di Hotel Arjuna Kota Batu). Jurnal Administrasi Bisnis, 72(1), 184-191.

Pusparani, A., \& Krisnawati, A. (2019). Analisis Pengaruh Financial Literacy Dan Financial Attitude Terhadap Financial Behavior Pada Siswa Sekolah Menengah Pertama Di Kota Bandung. Jurnal Mitra Manajemen, 3(1), 72-83.

Salim, Muhartini, et al. "Indonesian Millenials Online Shopping Behavior." International Review of Management and Marketing, vol. 9, no. 3, 2019, pp. 41-48. ProQuest, https://search.proquest.com/docview/22 88758759 ? accountid $=6724$.

Topbrand-award.com, "Top Brand Index", $2019 . \quad$ https://www.topbrandaward.com/top-brandindex/?tbi_find=Gojek (Diakses pada 20 Juni 2020)

Wahyuni, R. C., \& Waloejo, H. D. (2020). Pengaruh Kualitas Pelayanan, Harga, Dan Citra Perusahaan Terhadap Keputusan Penggunaan Jasa Pt Pos Indonesia (Persero) Kantor Pos Semarang. Jurnal Ilmu Administrasi Bisnis, 10(1), 349-356.

Yunanto, T. K. (2016). Pengaruh perceived ease of use, word of mouth, dan brand image terhadap keputusan penggunaan layanan jasa transportasi gojek di Kota Tangerang Selatan (Bachelor's thesis, UIN Syarif Hidayatullah Jakarta: Fakultas Ekonomi dan Bisnis, 2016). 
Nababan et al, JOBS Vol. 6, No.2, Des. 2020, p:111 - 122 